\title{
Teaching Design Strategy of Innovation and Entrepreneurship Course of College Students
}

\author{
Yongchun Piao \\ Normal College of Yanbian University \\ Yanji, China 133002
}

\author{
Jinzhong Ma \\ Normal College of Yanbian University \\ Yanji, China 133002
}

\begin{abstract}
After entering twenty-first century, network technology, digital technology and media technology have gradually penetrated into all aspects of human life. The talents cultivated by countless countries in the world have made remarkable achievements relying on these technologies, and the results are inseparable from two keywords, namely, innovation and entrepreneurship. From the twenty-first century, colleges and universities in China have gradually attached importance to the construction and development of innovation and entrepreneurship education. The ultimate goal of innovation and entrepreneurship education is not only to cultivate talents with basic entrepreneurship quality and entrepreneurial development potential, but also to cultivate talents with innovative and entrepreneurial practice and development. This paper teases out and analyzes the current situation and future trend of the development of innovation and entrepreneurship education and course construction by using documentary method. Combining with modern constructivism theory and the course of Creativity and Production of Micro-video in colleges and universities, it has developed a teaching strategy for learners' personality characteristics, teaching platform selection, teaching content selection, teaching process implementation, curriculum assessment design, and teaching plans.
\end{abstract}

Keywords-colleges and universities; innovation and entrepreneurship education; teaching strategies

\section{INTRODUCTION}

With the introduction of the national development strategy of "mass entrepreneurship and innovation", the reform of talent training mode to strengthen students' innovative spirit, entrepreneurship awareness and innovation and entrepreneurship ability in colleges and universities is increasingly valued by colleges and universities and favored by students. According to the spirit of the documents, Opinions on Deepening the Reform of Innovation and Entrepreneurship Education in Colleges and Universities[1] of General Office of the State Council, Opinions on Vigorously Promoting Innovation and Entrepreneurship Education in Colleges and Universities and Self-employment of College Students[2] of the Ministry of Education, and Suggestions on Deepening the Reform of Education and Teaching in Colleges and Universities to Promote Innovation and Entrepreneurship of College Students[3] of General Office of Jilin People's Government, colleges and universities regard innovation and entrepreneurship education as a strategic breakthrough to promote the comprehensive reform of education and teaching, and establish the advanced concept of innovation and entrepreneurship education. They take the improvement of students' sense of social responsibility, innovation spirit and entrepreneurial ability as the core, focus on updating the talent training model and course system, and aim at implementing the innovative and entrepreneurial programs of college students, so as to integrate innovation and entrepreneurship education into the whole process of talent cultivation and vigorously promote the work of innovation and entrepreneurship education of colleges and universities.

Innovative and entrepreneurial education has been first proposed by the United States and has been explored and practiced by innovative and entrepreneurial talents for half a century, and then Silicon Valley, a world-famous kingdom of electronic industry and computer industry, has been born in the southern part of the San Francisco Bay Area, America. With its innovation power education training, Switzerland has ranked the top in the global innovation index in 7 years[4], and has ascended among the developed countries in the world from the poorest countries in Europe. With the continuous development of China's economy and ever-increasing per capita GDP, the focus of higher education in the twenty-first century should be placed on innovation and entrepreneurship education. The Chinese government emphasizes on reconstructing innovation and entrepreneurship education, and colleges and universities create innovative and entrepreneurial education courses, which not only opens up a new way for the employment of college graduates to reduce social employment pressure, but also brings new opportunities for the country's economic prosperity and market activity. Therefore, an existing and meaningful research topic is to offer innovative and entrepreneurial courses and to carry out effective teaching design for the course in colleges and universities.

\section{THE CONNOTATION OF INNOVATION AND ENTREPRENEURSHIP EDUCATION}

According to the definition of innovation and entrepreneurship education given by the International Conference on Innovation and Entrepreneurship Education at Tokyo, innovation and entrepreneurship education aims to cultivate these persons who have pioneering personality, and the content of innovation and entrepreneurship education includes the cultivation of pioneering spirit, adventurous spirit, entrepreneurial ability, independent work ability, and technical, social, and managerial skills[5]. The ultimate goal of 
innovation and entrepreneurship education is not only to cultivate talents with basic entrepreneurship quality and entrepreneurial development potential, but also to cultivate talents with innovative and entrepreneurial practice and development. The Ministry of Education of China has put forward in the Opinions on Vigorously Promoting Innovation and Entrepreneurship Education in Colleges and Universities and Self-employment of College Students: "colleges and universities open up innovation and entrepreneurship education, and actively encourage college graduates to start their own businesses, and it is an important measure to thoroughly study and practice the scientific outlook and construct innovation-oriented country, a necessary way to deepen the reform of higher education teaching and cultivate the innovative spirit and entrepreneurial ability of the students, and a wise decision to implement the policy of promoting employment through entrepreneurship and promote employment of college students"[6].

Innovation and entrepreneurship education needs to rely on effective innovation and entrepreneurship courses to transform educational concept into educational practice [7]. Innovation and entrepreneurship course is the total of the learning process of innovation and entrepreneurship education and the demands that learners need to study innovation and entrepreneurship education. It is a purposeful and planned innovation and entrepreneurship education activity, and the total of the design and establishment of teaching objects, teaching content, teaching method, and the implementation process of teaching plan and teaching programme.

\section{RESEARCH STATUS OF INNOVATION AND ENTREPRENEURSHIP EDUCATION OF DOMESTIC AND FOREIGN COUNTRIES AND COLLEGES AND UNIVERSITIES}

The United States is the earliest country in the world to develop innovation and entrepreneurial education and get rapid development speed. Before the establishment of innovative and entrepreneurial professional education courses in colleges and universities in America, in folk, some independent organizations have begun to spread knowledge and skills on innovation and entrepreneurship. For example, Horace Moses established the Junior Achievement in 1919 to help ordinary students set up their own company[8]. Innovation and entrepreneurship education was first introduced from the first course of Management of New Enterprise that set up entrepreneurial education for the first time by Professor Myles Mace in Harvard Business School in 1947, and it has a history for 71 years. Stanford University and Babson College respectively started to create the entrepreneurship major for students who had entrepreneurial interests and potential at the stage of undergraduate education in 1949 and 1968, and offered professional major courses. Next, Massachusetts Institute of Technology held the MIT Alumni Association Seminar Series on how to use the research results and innovative technologies to create a business, and the setting of this course realizes the interpenetration of knowledge among subjects.

The innovation and entrepreneurship education in Korea began with the "entrepreneurship and project analysis" lecture of Dongguk University in 1987. After the lecture, the innovation and entrepreneurship education in Korea has not developed rapidly. In 1999, Hoseo University and Soongsil University first opened the entrepreneurship education major at the stage of undergraduate. The development history of innovation and entrepreneurship education in colleges and universities in Korea has opened a new chapter at this point. After more than 30 years of development, based on the report of middle and small-sized enterprises window, the innovation and entrepreneurship education in colleges and universities in Korea has formed a basic system of entrepreneurship education which takes 10 entrepreneurship graduate schools, including University of Science and Technology of Kyungnam, Chung-Ang University, Hansei University, Yewon Arts University, Hoseo University, Kookmin University, Keimyung University, Pusan National University, Sungkyunkwan University and Yonsei University, as the core and radiates Korea.

The innovation and entrepreneurship education in Japan started in 1960s when the economy grew at a high level, but at that time, innovation and entrepreneurship education did not receive attention. In 1995 and 1996, the Japanese government promulgated the Basic Law of Science and Technology and proposed the concept of "cultivating talents with innovative spirits". In 2006, the Japanese government amended the Company Law, and proposed that one could create his own company as long as he had 1 Yen. This series of national policies has greatly facilitated Japanese entrepreneurs. Meanwhile, colleges and universities in Japan have attached great importance to the faculty when setting up innovative and entrepreneurial education courses. Most teachers have both a solid theoretical foundation and practical experience of successful innovation and entrepreneurship, which provides a strong reserve force for promoting the development of innovation and entrepreneurship education in Japan.

China set off a hot wave of innovation and entrepreneurship after Premier Li Keqiang participated in the third Summer Davos Forum held in Dalian in 2009 and proposed the keywords of mass entrepreneurship and grassroots entrepreneurship. In November 2014, Premier Li Keqiang attended the first World Internet Conference held in Wuzhen, Jiaxing, Zhejiang, and emphasized that the Internet is a new way for mass entrepreneurship and innovation. In March 2015, Prime Minister Li Keqiang first mentioned the "Internet +" action plan in the government report released at the Third Session of 12th National People's Congress. On June 11, 2015, under the guidance of the Ministry of Education, China established the Innovation and Entrepreneurship Education Alliance in Colleges and Universities in China with Tsinghua University as the core. The same year, more than 200,000 college students from 1,800 colleges and universities across the country participated in the first Chinese "Internet +" Innovation and Entrepreneurship Competition for College Students organized by the Ministry of Education. The founding team of Ofo Bicycle which once had a debt of 6 million ranks the third place in the finals of the second Chinese "Internet +" Innovation and Entrepreneurship Competition for College Students, but now it has owned hundreds of millions money. 


\section{TEACHING STRATEGIES OF INNOVATION AND ENTREPRENEURSHIP CURRICULUM}

\section{A. Analysis on Learner's Personality Characteristics}

For the innovation and entrepreneurship curriculum, it is especially significant to analyze the characteristics of learners. The unique personality characteristics that affect the learning process of learners can be processed with the following three aspects: cognitive ability, cognitive levels and learning style. The course is designed for college students who have innovative and entrepreneurial awareness. They can be these college students who are interested in musical composition, or who are good at writing scripts and have unrestrained imagination, or who want to try to shoot and there is no limitation for specialty and grade. Through the concept that "the ability to acquire knowledge and learn knowledge is more important than mastering knowledge itself" advocated by connectivism, we can analyze the cognitive ability of learners. Cognitive ability refers to the ability of human brain to process, store and withdraw information, that is, the people's learning ability for the formation, performance of objects and other relations, development trends and directions and basic law, and it is the most important psychological condition for people to successfully complete their activities. After 9 years of compulsory education and 3 years of senior high school education, aiming at creativity and independent study, college students have developed imagination and mature logical thinking ability, and they have sufficient ability to understand and store knowledge." The innovation cognitive level should include two aspects: innovation cognition and innovation consciousness. Innovation cognition refers to the related understanding on the concept of innovation, the importance of innovation and so on; innovation consciousness requires a positive attitude towards innovation, diverges the thoughts and seeks innovation. After considering the learning style of learners in the process of teaching, the learning motivation of learners will be effectively stimulated and maintained, and their learning activities will become easy and simple and will get twofold results with half the effort. This course should take into account students with different learning styles, so that each student can develop their strengths.

\section{B. Selection Strategy of Teaching Platform}

After entering 21 st century, people's food, clothing, shelter and means of traveling have gradually become inseparable from Internet and network technologies. People can not only use the Internet to obtain information, complete work, carry out social intercourse and recreational activities, but also can engage in teaching or online learning, and can integrate a large number of teaching resources under the cloud environment. This course will firstly use the excellent and professional teachers and professional engineers of video production companies to jointly produce and improve the cloud resources of online teaching courses, such as teaching videos, lecture notes and so on, take Superstar Learning Expert as a teaching platform, classify and collect a large number of teaching resources with the help of powerful computing system of the cloud, facilitate the learners' needs for course knowledge retrieval and apply the learning style of connectivism to help learners grow their knowledge in online learning; complete the distribution and construction of online teaching courses on the teaching platform of Superstar Learning Expert; set up question board and communication board on the teaching platform of Superstar Learning Expert. Teachers and learners can complete online teaching guidance, communication and exchange any time anywhere, and it can realize the interaction between learners and teachers; at the same time, relying on the non-linear editing laboratory of educational technique major of Normal College of Yanbian University, perfect the construction of micro-video maker space of learning style of connectivism. The individual learner uses the knowledge obtained from the following modules, such as source area, online course, communication board, works show and so on, in Superstar Learning Expert to form a new network, which provides continuous learning for learners and shows the learning ideas of connectivism. At the same time, in order to protect the intellectual property of creator, the maker space is only publicly available to all learners of the course and is only used to practice, produce and share the micro-video works created by learners and will not be disclosed to external websites.

\section{Selection Strategy of Teaching Content}

The teaching content of micro video production not only requires teachers to learn the technology of micro video production (Software Edius7.4 introduction, editing, special effects, music, subtitling and recording technology), but also needs their professional knowledge such as media aesthetics for auxiliary teaching, so as to help the learns to clearly distinguish whether the a micro video creation is of high quality or beautiful. The teaching content of micro video production should not only include the teaching content of theory knowledge of the "teaching", but also the teaching content of practical operation of "practicing". After the learner studies all the basic theoretical knowledge, this course will provide the learner with creative teaching and practical space (micro video maker space), and help the creator to complete the support and guidance of technologies including video capture, recording and editing systems and to complete the most satisfactory micro video (MV, microfilm, micro lecture) works of the learners.

\section{Implementation Strategy of Teaching Process}

The learners can carry out independent study on Superstar Learning Expert according to the schedule time specified by the course. The online course not only includes the knowledge content that the class needs to teach, but also the learning style that combines the interaction of learners and content advocated by connectivism The online course sets phased questions and it can summarize the learning effect of the learner in this course through the question content counted by the backstage. Based on the learning method of learner-teacher interaction advocated by the connectivism, if learner has some questions that he cannot understand, he can raise a question on the question board. These learners who have no questions will learn the course in the next class in the specified time. This course both has online virtual teaching and practical classroom teaching, which combines two teaching methods to teach. After the completion of all the theoretical basic knowledge of the online virtual course, the actual classroom teaching is 
centered on the learner, and provides distribution of learning projects, creativity discussion, and technical issues solving and guidance. Based on the learning method of learner-learner interaction advocated by connectivism, the learning project takes the form of 5 people in a group, and the combination and allocation of group members should comply with the principle of voluntariness, but it should take equal role and group members perform their duties. All the group members should jointly collaborate and complete the initial theme, creativity, division of labor, scripting, production, completion, publication of micro-videos.

\section{CONCLUSION}

Through "learning in the practice", cultivates students' appreciation in video culture and art and cultivates their consciousness of innovation, innovative thinking and entrepreneurial ability of video artworks and products. The study finds that micro-video creativity and production course teaching should focus on learner's personality analysis, teaching platform selection, teaching content selection, teaching process implementation, and course assessment design. In this way, the students can develop a more broad thinking perspective, a more intelligent way of learning and a stronger practical ability in micro video creativity and production. The study also finds that we rationally use advanced science and technology, integrate excellent teaching ideas into the teaching implementation process, take the learner as a center, combine course teaching and practical teaching, so that the designed teaching strategy can improve the learning effect of the learners, cultivate learners' divergent and innovative thinking, enhance learners' innovative ability, and better cultivate innovative and entrepreneurial talents in micro video.

\section{REFERENCES}

[1] Opinions on Deepening the Reform of Innovation and Entrepreneurship Education in Colleges and Universities [Z]. G. B. F. (2015) No. 36. 《深 化高等学校创新创业教育改革的实施意见》 [Z]. 国办发(2015)36 号.

[2] Opinions on Vigorously Promoting Innovation and Entrepreneurship Education in Colleges and Universities and Self-employment of College Students [Z]. J. B. (2010) No. 3. 《大力推进高等学校创新创业教育和 大学生自主创业工作的意见》[Z].教办(2010)3 号.

[3] Suggestions on Deepening the Reform of Education and Teaching in Colleges and Universities to Promote Innovation and Entrepreneurship of College Students [Z]. J. Z. B. F. (2015) No. 43. 《深化高等学校教育 教学改革促进大学生创新创业的实施意见》[Z].吉政办发(2015)43 号.

[4] Qiu Ming, Guo Xiaoqiang. The Practices and Inspiration of the Innovation Power Education and Training in Switzerland [J]. Journal of China Executive Leadership Academy Jinggangshan, 2017, 10 (02): 140-144. 邱明, 郭小强.瑞士开展创新力教育培训的做法与启示[J].中 国井冈山干部学院学报,2017,10(02):140-144.

[5] Wang Xianfang, Meng Ke. On the Reconstruction of Innovation and Entrepreneurship Education System in Colleges and Universities [J]. Education Teaching Forum, 2012 (02): 118-120. 王贤芳,孟克.论高校 创新创业教育体系之重构[J].教育教学论坛,2012(02):118-120.

[6] Same as [2]

[7] Bao Guilian, Feng Aiqiu, Xiao Zhangke, Yang Fang, Yang Pei. Analysis and Thinking on the Situation of Innovation and Entrepreneurship Education of Colleges and Universities in China [J]. China Electric Power Education, 2011 (35): 22-23. 鲍桂莲,冯爱秋, 肖
章柯,杨芳,杨沛.对国内高校创新创业教育状况的分析与思考[J].中 国电力教育, 2011(35):22-23.

[8] Shui Mei, Zhang Haoyu, Zhan Bihua, Gu Guiju, Liu Junfeng, Zhang Huiying, Jin Yingzi, Li Lili, Sun Tao. Research on the Construction of Innovative and Entrepreneurial Education Course in the United States [J]. Economic Research Guide, 2015 (06): 252-253. 水梅,张昊宇,詹碧 华,谷桂菊,刘俊峰,张慧英,金英子,李力力,孙涛.美国创新创业教育课 程建设研究[J].经济研究导刊,2015(06):252-253.

[9] Robinson P.The Education Entrepreneurs:ANew Era of Entrepreneurial Education is Beginning[J].American Journal of Small Business, 1995(4):37-53. 